\title{
Evaluation of Polyherbal Formulation (Kemite) on Cafeteria Diet-induced Obesity in Wistar Rats
}

\section{GNANGORAN Boua Narcisse*, TRAORÉ Moussa, YAPO Angoué Paul}

Nangui Abrogoua University, Nature Sciences Training and Research Unit, Laboratory of Physiology, Pharmacology and Pharmacopoeia, 02 P.O. Box 801 Abidjan 02, Côte d'Ivoire.

*Corresponding author's E-mail: gnangorannar.sn@univ-na.ci

Received: 03-07-2021; Revised: 24-08-2021; Accepted: 05-09-2021; Published on: 15-09-2021.

\section{ABSTRACT}

Obesity is a chronic disorder of global prevalence and associated with morbidity and mortality. This pathology is a real public health problem. The work was undertaken to evaluate the antiobesity efficacy of aqueous extract of Kemite in cafeteria diet induced obese Wistar rats for a period of 28 days. Aqueous extract of Kemite (AEK) was prepared by hot extraction method. Female Wistar rats weighing 124-170 g were divided into different groups i.e. Normal control, cafeteria control and aqueous extract of Kemite at dose of $200 \mathrm{mg} / \mathrm{kg}$ bw. The antiobesity activity is estimated in terms of body weight gain, food intake, serum triglycerides (TG), Total cholesterol (TC), LDL cholesterol (LDL-C), HDL cholesterol (HDL-C), VLDL cholesterol (VLDL-C), blood glucose (BG), ASAT and ALAT activities, atherogenic index, coronary risk index and liver and fat pad weights. Results showed Cafeteria diet fed rats for 28 successive days significantly increased the body weight, food intake, ASAT and ALAT activities, liver and fat pad weights, atherogenic index, coronary risk index TG, TC, LDL, VLDL, BG and not influenced HDL levels. Rats treated with extract for 28 successive days along with cafeteria diet reversed the effects induced by cafeteria diet. In conclusion, this study revealed that AEK may be a natural and safe remedy for the prevention and control of obesity.

Keywords: Obesity, Cafeteria diet, Aqueous extract of Kemite, Wistar rats.

QUICK RESPONSE CODE $\rightarrow$

DOI:

10.47583/ijpsrr.2021.v70i01.020

DOI link: http://dx.doi.org/10.47583/ijpsrr.2021.v70i01.020

\section{INTRODUCTION}

besity is characterized by an increase in fat mass accumulation and body weight gain ${ }^{1}$. It is associated with an increased risk of many chronic conditions, including diabetes, dyslipidemia, stroke, cardiovascular disease (CVD), and certain cancers, and it is also associated with an elevated risk of total mortality and death from $\mathrm{CVD}^{2}$. Obesity is a global public health problem in terms of morbidity, mortality, and its associated economic burden ${ }^{3}$.

World Health Organization (WHO) has estimated that it affects 650 million adults worldwide, with this burden projected to increase to one billion globally by $2030^{4}$. In West Africa, one of WHO's Africa subregions, about 52 million people are with obesity, making it one of the subregions burdened with the obesity epidemic ${ }^{5}$.

Data on obesity in Côte d'Ivoire are scarce and old, and we lack a good description of the entire population as the data are focused on a small part of the population living mainly in Abidjan. In the earliest study, realized in 2015, Abidjan showed a prevalence of overweight at $43 \%$ among women with $13 \%$ of obesity ${ }^{6}$. Furthermore, the prevention and control of non-communicable disease are almost neglected ${ }^{7}$.

Adherence to low-calorie diets, changing dietary habits, increasing physical activity levels and taking anti-obesity supplements and medications are the major approaches for the treatment of obesity ${ }^{8,9}$. Anti-obesity medications are mainly described via three potent mechanisms including enhancing energy expenditure, suppression appetite and inhibition of gastrointestinal enzymes involved in weight loss ${ }^{8,10}$. In this respect, development of efficient agents for inhibiting the metabolism of carbohydrates and fat digestion and absorption leads to the reduction of calorie intake, promotion of weight loss, and management of possible complications of obesity. However, current available synthetic drugs such as acarbose, orlistat and miglitol have been associated with some gastrointestinal problems including bloating, diarrhea, flatulence and abdominal discomfort ${ }^{11}$. The literature indicates a relationship, to our knowledge, of bioactive components in plant foods and their links to obesity.

In traditional system of medicine in Côte d'Ivoire, polyherbal formulations are used as drug of choice rather than individual. Various herbal formulations are well known for their antiobese effects. A Polyherbal formulation namely Kemite contained aqueous extracts of Curcuma longa, Mentha spicata, Zingiber officinale and Piper nigrum was prepared and investigated. The ingredients in the formulation have been reported to possess antioxidant, body weight lowering, antiinflammatories and digestive stimulant properties.

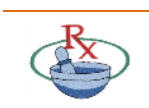


Thus, the present study has been to evaluate the antiobesity activity of polyherbal formulation in diet induced obesity in Wistar rats.

\section{MATERIALS AND METHODS}

\section{Animals}

All experiments related to diet induced obesity were carried out with female Wistar rats of the species Rattus norvegicus. Animals were six to eight weeks old and weighed between 124 and $170 \mathrm{~g}$. They were bred in animal house of Physiology, Pharmacology and Pharmacopeia laboratory of the University of Nangui Abrogoua (Abidjan, Côte d'Ivoire) according to the principles for the care and use of laboratory animals of the Ethical Committee of the University (Nangui Abrogoua, Abidjan, Côte d'Ivoire). The rats were acclimated to temperature of $25{ }^{\circ} \mathrm{C}$ and an alternation of 12 hours of light and 12 hours of darkness. They were fed daily with IVOGRAIN ${ }^{\circledR}$ pellets and had access to water at will in their bottles.

\section{Polyherbal formulation}

Polyherbal formulation called "Kemite" contained rhizomes of Curcuma longa (zingiberaceae), leaves and stems of Mentha spicata (Lamiaceae), rihzome of Zingiber officinale (zingiberceae) and fruits of Piper nigrum (Piperaceae). "Kemite " was provided by health practitioner from Nangui Abrogoua University (Abidjan, Cote d'Ivoire). The collected plants were authenticated at the Botany laboratory of University of Nangui Abrogoua.

\section{Preparation of extract aqueous of " Kemite "}

The ingredients (rhizomes of Curcuma longa, leaves and stems of Mentha spicata, rihzome of Zingiber officinale and fruits of Piper nigrum) were individually dried in shade, powdered and then mixed in mentioned proportion with help of suspending agent.

For the preparation of the aqueous extract of "Kemite" obtained according to the method for traditional use with slight modifications. Hundred (100) gm of the mixture was dried, ground and subjected to extraction by infusion in 1 $\mathrm{L}$ of distilled water at $100^{\circ} \mathrm{C}$ for $15 \mathrm{~min}$. This solution obtained was cooled and double filtered on hydrophilic cotton and Whatman filter paper $\left(\mathrm{N}^{\circ} 1\right)$. Half a liter of distilled water at $100{ }^{\circ} \mathrm{C}$ was added to the residue for a second infusion for $10 \mathrm{~min}$. The mixture was also filtered under the same conditions. The filtrates were evaporated, oven dried at $50{ }^{\circ} \mathrm{C}$ for 48 hours to obtain crude and stored in a refrigerator at $4^{\circ} \mathrm{C}$ until use. The desired dose $(\mathrm{mg}$ of extract aqueous extract of plant per kg body weight) was then prepared and reconstituted in $10 \mathrm{ml}$ of $\mathrm{NaCl} 0.9$ $\%$. The extract obtained was then given orally to different groups of female Wistar rats at a dose of $200 \mathrm{mg} / \mathrm{kg}$ body weight. The dose of $200 \mathrm{mg} / \mathrm{kg}$ was used according to the therapeutic dose.

\section{Acute Toxicity Study}

The acute toxicity studies were conducted as per the Organization for Economic Cooperation and Development
(OECD) guidelines $425^{12}$. Five healthy female Wistar rats (124-170 g) were fasted for twelve hours and orally given of aqueous extract of "Kemite". This formulation was suspended in $\mathrm{NaCl} 0.9 \%$ and administered by gavages at single dose of $5000 \mathrm{mg} / \mathrm{kg}$ (all four medicinal plants in equal proportional). The rats were observed for physical signs first for three hours and further for $72 \mathrm{~h}$. The experiment was terminated after $14 \mathrm{~h}$ of observations.

\section{High fat diet Induced obesity in experimental rats}

\section{Preparation of cafetaria diet}

A modified method of some authors ${ }^{13}$ was used. Normal diet (ND) was a standard pellet diet containing Crude protein (15\%), crude fat (3.54\%), crude fibre (14.57\%), calcium $(10.73 \mathrm{~g} / \mathrm{kg})$, phosphorus $(6.5 \mathrm{~g} / \mathrm{kg})$, sodium $(0.15 \%)$ and other $(7.94 \%)$. Cafeteria diet (CD) was a hyper caloric and lipid diet and was prepared by mixing the below constituents in fixed strength. This diet consisted of $50 \%$ normal diet and $50 \%$ of a mixture of tinned corned beef pâté, biscuits, cheese, potato crisps, peanuts, chocolate and palm oil in a proportion 2: 2: 2: 1: 1: 1: 1. Rats were fed with prepared cafeteria diet and water ad libitum for the period of 28 days. Weight gain in animals was monitored regularly.

\section{Treatment protocol}

Fifteen healthy female albino wistar rats were randomly divided into three groups I, II and III of five (5) rats each, with their initial body weight (124-170g) measured. The following protocol of dose and diet administration in experimental groups was followed:

Group-I (NC), served as normal control, rats fed with normal diet (Pellet) and received orally $\mathrm{NaCl} 0.9 \%$ for 28 days;

Group-II (CD), served as cafeteria control, rats fed with cafeteria diet and received orally $\mathrm{NaCl} 0.9 \%$ for 28 days;

Group-III (CD+AEK), served as group test, rats fed with cafeteria diet and treated with $200 \mathrm{mg} / \mathrm{kg}$ body weight (bw) of aqueous extract of "Kemite " for 28 days.

All the test compounds were administered orally once a day before food ${ }^{14}$.

\section{Collection of blood}

On day 28 of the experiment the rats were anaesthetized by ether and blood was collected from retro orbital plexus in eppendorf tubes. Serum was separated by centrifugation at $3000 \mathrm{rpm}$ for $10 \mathrm{~min}$. Then, it was stored at $-20^{\circ} \mathrm{C}$ and used for estimation of various biochemical estimations. After collection of blood samples, the rats were sacrificed by over dose of ether anesthesia. The liver and fat pad were excised, cleaned in $\mathrm{NaCl} 0.9 \%$ solution, placed on absorbent papers and weighed (absolute organ weight in grams).

The relative organ weight (ROW) of each animal was then calculated as follows ${ }^{15}$ : 
ROW $(\%)=[$ Absolute organ weight $(\mathrm{g}) \div$ Body weight of rat on sacrifice day $(\mathrm{g})] \times 100$.

\section{Observation Parameters}

\section{Body Weight and food intake}

Body weight change and food intake was measured according to method by ${ }^{16}$. The body weight and food intake of the rats in all groups were recorded every day by using digital weighing balance.

\section{Biochemical parameters}

Serum was used for estimation of lipid profile, blood glucose level and lever enzymes. Serum total cholesterol (TC), HDL-C (CHOD-PAP method), triglyceride (TG) (GPOPAP method) and blood glucose (GOD POD method) were estimated by enzymatic colorimetric methods using standard commercial kits.

LDL cholesterol (LDL-C) and VLDL (Very Low Density Lipoprotein) Cholesterol (VLDL-C) were calculated by using the following formula ${ }^{17,18}$ :

LDL-C $=($ Total-C)-HDL-C- $(T G / 5)$ and VLDL-C= TG/5.

In regards to liver enzymes including aspartate Aminotransferase (AST) and Alanine aminotransferase (ALT) levels were carried out using standard techniques ${ }^{19}$.

The Atherogenic index ( $\mathrm{Al}$ ) and coronary risk index (CRI) were calculated using the following formulae ${ }^{18,20}$ :

$\mathrm{Al}=\mathrm{LDL}$ Cholesterol / HDL Cholesterol and CRI = Total Cholesterol / HDL Cholesterol

\section{Statistical analysis}

The results were expressed as Mean \pm S.E.M. The Statistical Analysis was carried out using analysis of one-way variance (ANOVA) followed by Turkey-kramer's test. $p$ values $<0.05$ were considered as significant. The entire statistical analysis and graphical representation were performed using the GraphPad Prism software version 5.01 for Windows (GraphPad Software Inc., San Diego, MO, Califormia / USA, 2007).

\section{RESULTS}

\section{Acute toxicity studies}

The oral administration of aqueous extract of "Kemite" (AEK) at the dose of $5000 \mathrm{mg} / \mathrm{kg}$ bw weight had not shown any signs of toxicity and mortality was not observed up to day 14 .

\section{Assessment of anti-obesity activity}

\section{Effect of AK on body weight and food intake}

Effect of AEK on Body weight gain and food intake was shown in Figure 1 and 2. A substantial increase $(p<0.05)$ in body weight had been observed in cafeteria control group when compared with normal control rats on day 28 . Oral supplementation of AEK significantly reduced the body weight gain when compared with cafeteria control group on days 21 and 28. Food intake in AEK treated animals had also decreased when compared with cafeteria control.

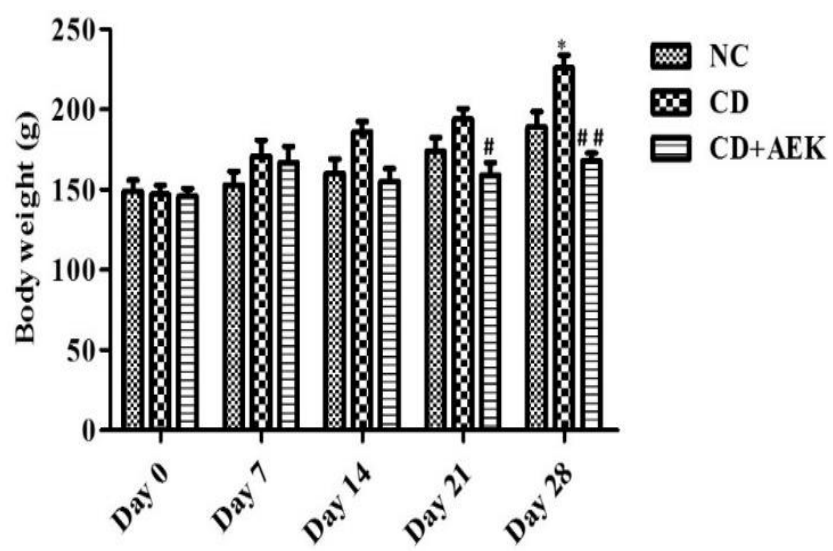

Figure 1: Effect of aqueous extract of Kemite on body weight

Values are expressed as Mean \pm SEM ( $n=5$ per group). ${ }^{*} p<0.05$ compared to NC; $\# p<0.05, p<0.05$, compared to DC. NC: Normal diet; $C D$ : Cafeteria diet ; CD+AEK : Cafeteria diet+ aqueous extract of Kemite 200 mg/kg bw.

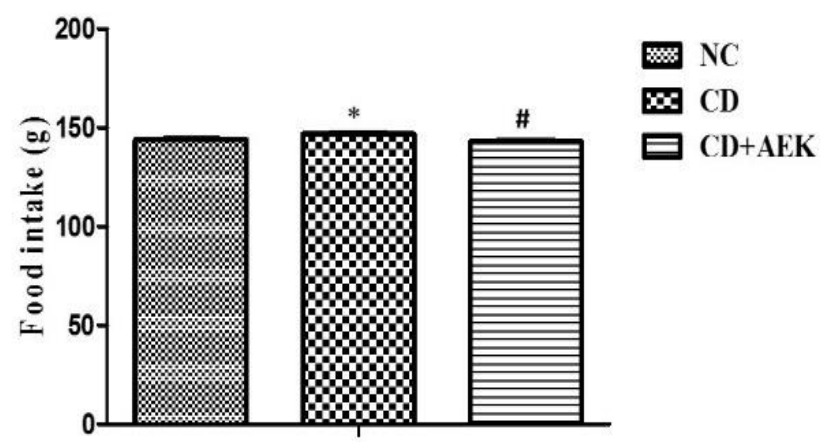

Figure 2: Effect of aqueous extract of Kemite on food intake

Values are expressed as Mean \pm SEM ( $n=5$ per group). ${ }^{*} p<0.05$ compared to NC; \#p<0.05 compared to DC. NC : Normal diet ; CD : Cafeteria diet ; CD+AEK : Cafeteria diet+ aqueous extract of Kemite $200 \mathrm{mg} / \mathrm{kg}$ bw.

\section{Effect of AEK on lipid profile}

Effect of AEK on lipid profile in cafeteria diet induced obesity was represented in Figure 3. Feeding cafeteria diet to group-II rats caused significant increase in the serum TC $(p<0.05)$ and TG $(p<0.001)$ levels as compared to rats which received normal diet. Wistar rats fed with cafeteria diet and treated with AEK (Group-III) significantly reduced TC $(p<0.05)$ and TG $(p<0.001)$ levels when compared with Group-II (cafeteria diet). In addition, cafeteria diet caused significant $(p<0.001)$ increase in LDL and VLDL levels in Group-II. Supplementation of AEK decreased significantly ( $p<0.001$ ) both LDL and VLDL levels when compared with cafeteria control rats. However, HDL levels did not change ( $p>0.05$ ) in Group-II rats compared to normal control (Group-I). In addition, administration of AEK did not influence HDL levels when compared with cafeteria control group.

\section{Effect of AEK on blood glucose level}


The results of blood glucose level are mentioned in Figure 3.

Blood glucose (BG) levels were significantly higher in cafeteria control (Group-II) compared to that of normal control. Group of rats fed with cafeteria diet and treated orally with AEK (Group-III) significantly reduced BG levels when compared with rats which received only cafeteria.
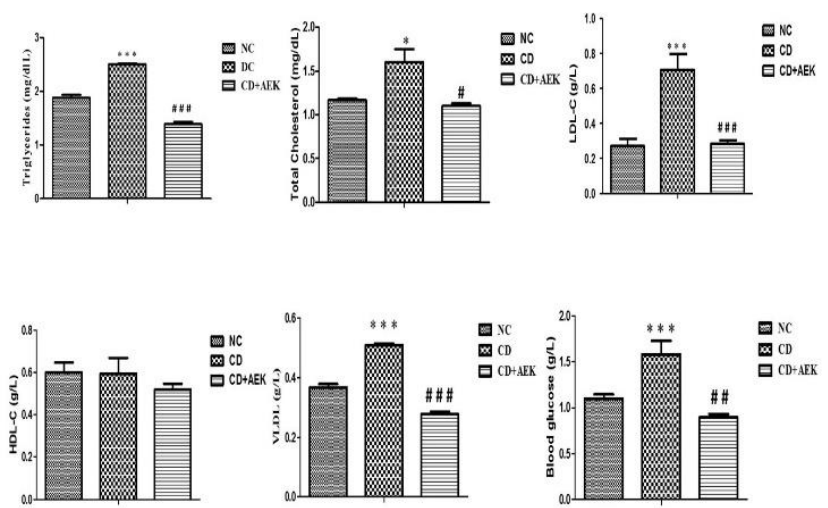

Figure 3: Effect of aqueous extract of Kemite on serum metabolites.

Values are expressed as Mean \pm SEM ( $n=5$ per group). ${ }^{*} p<0.05$,

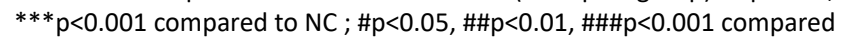
to DC. NC : Normal diet ; CD : Cafeteria diet ; CD+AEK : Cafeteria diet+ aqueous extract of Kemite $200 \mathrm{mg} / \mathrm{kg}$ bw.

Effect of AEK on atherogenic index and coronary risk index

Feeding of cafeteria diet increased significatly $(p<0.001)$ atherogenic index compared to rats fed with normal diet. Administration of AEK for 28 days along with cafeteria significantly $(p<0.01)$ decreased atherogenic index. In contrast, cafeteria diet did not influence $(p>0,05)$ coronary risk index when compared with normal control. Also, treated with AEK did not alter $(p>0,05)$ this parameter as compared with cafeteria diet control (Figure 4).

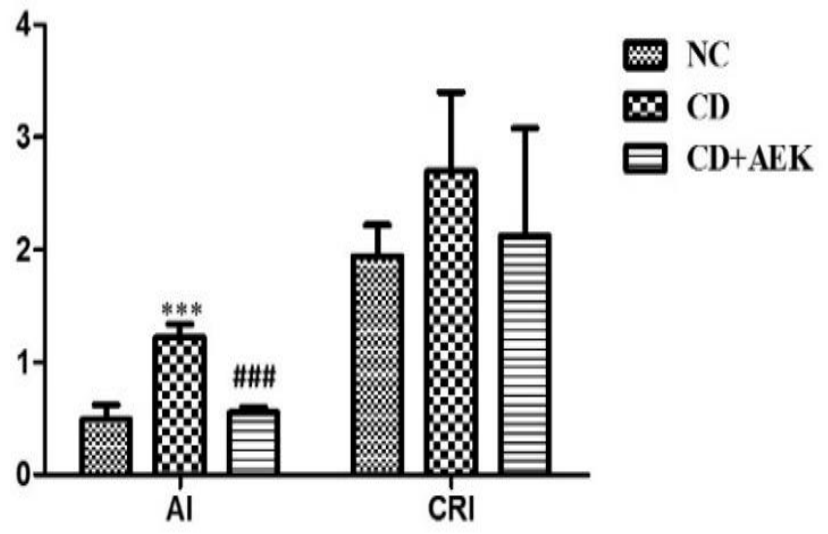

Figure 4: Effect of aqueous extract of Kemite on atherogenic index and coronary risk index

Values are expressed as Mean \pm SEM ( $n=5$ per group). ${ }^{* *} \mathrm{p}<0.001$ compared to NC ; \#\#\#p<0.001 compared to DC. NC : Normal diet ; CD : Cafeteria diet ; CD+AEK : Cafeteria diet+ aqueous extract of Kemite 200 $\mathrm{mg} / \mathrm{kg}$ bw.

\section{Effect of AEK on liver enzymes}

Serum alanine aminotransferase (ALT) and aspartate aminotransferase (AST) activities in Group-II rats were significantly $(p<0.001)$ increased when compared with normal control (Group-I). Rats fed cafeteria and treated with AEK (Group-III) showed significantly ( $p<0.001$ ) decrease of sera AST and ALT activities compared with cafeteria control. Results are shown in Figure 5.

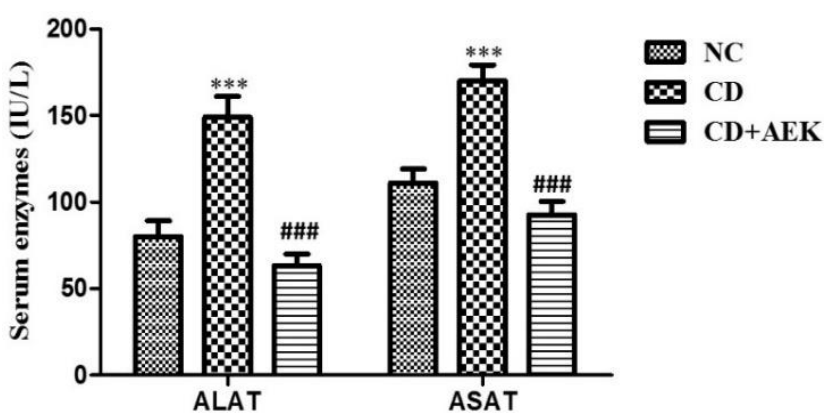

Figure 5: Effect of aqueous extract of Kemite on liver enzymes

Values are expressed as Mean \pm SEM ( $n=5$ per group). ${ }^{* * *} p<0.001$ compared to NC ; \#\#\#p<0.001 compared to DC. NC : Normal diet ; CD : Cafeteria diet ; $C D+A E K$ : Cafeteria diet+ aqueous extract of Kemite 200 $\mathrm{mg} / \mathrm{kg}$ bw.

\section{Effect of AEK on relative organ weight}

No significant change in relative liver weight in Group-II rats (Cafeteria control) as compared to normal control (Group-I), except relative fat pad weight was increased significantly ( $p<0.001$ ). However, AEK treatment on rats fed cafeteria diet decreased significantly $(p<0.001)$ in relative fat pad weight compared to cafeteria group (Figure 6).

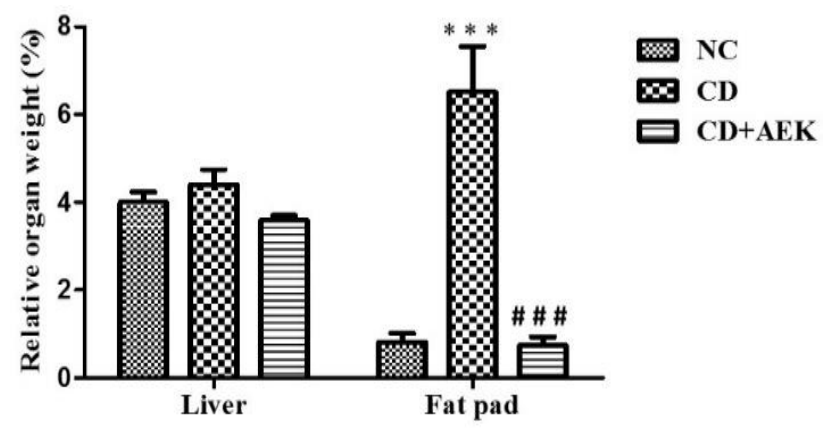

Figure 6: Effect of aqueous extract of Kemite on relative organ weight

Values are expressed as Mean \pm SEM ( $n=5$ per group). ${ }^{* * *} p<0.001$ compared to NC ; \#\#\#p<0.001 compared to DC. NC : Normal diet ; CD : Cafeteria diet ; CD+AEK : Cafeteria diet+ aqueous extract of Kemite 200 $\mathrm{mg} / \mathrm{kg}$ bw.

\section{DISCUSSION}

The apparent lack of morbidity and absence of mortality in the determination of median lethal dose (LD 50 ) of aqueous extract of "Kemite" indicate that $L_{50}$ is exceeds $5000 \mathrm{mg} / \mathrm{kg}$ bw. According to some authors ${ }^{21}$, a chemical or drug candidate with an LD50 of $5000 \mathrm{mg} / \mathrm{kg}$ bw or greater is acutely safe and can be used for therapeutic 
purposes. Based on acute toxicity studies, aqueous extract of "Kemite" is not toxic by oral route. Therefore, the polyherbal formulation called Kemite could be considered as safe for its traditional use by populations.

The results showed that cafeteria diet (CD) was fed to Wistar, rats for 28 consecutive days induced obesity. This study confirms other findings that Wistar rats fed an cafeteria diet for a long period of time, develop obesity ${ }^{22}$, 23 .

Cafeteria diet significantly increased in body weight, relative fat pad body weight and food intake. But, no significant variation was observed in the relative liver body weight. Treatment with aqueous extract of "Kemite" (AEK) in dose of $200 \mathrm{mg} / \mathrm{kg}$ bw inhibited increase in body weight and relative body weight of fat pad resulted in reduction of body weight and relative body weight of fat pad in CD fed rats. This result demonstrate that AEK possesses weight reducing activity. This reduction in body weight may partially be mediated via the inhibition of pancreatic lipase activity and via the activation of thermogenesis through the stimulation of the $\beta$-adrenergic receptors ${ }^{24}$. Furthermore, the decrease in the weight may due to decrease fat pad body weight by reducing the formation of new adipocyte from precursor cells or decreased adipocyte size due to fat storage (adipocyte hypertrophy) ${ }^{25}$.

Researchers showed that body weight gain due to hyperphagia in rats ${ }^{26}$. CD fed rats consumed more food than normal diet fed Wistar rats. EAK effectively decreased food intake in CD fed rats.

One of the main concerns of obesity is the presence of dyslipidaemia, since this significantly increases the risk of cardiovascular disease ${ }^{27}$. Ours results showed that compared to that of NC, serum TG, TC, LDL-C, VLDL-C levels were significantly elevated in $C D$ fed rats and not influenced HDL-C level, indicating that CD feeding induced hyperlipidemia in rats. Similarly, blood glucose level was significantly increased in CD group as compared to normal diet group. The raise in lipid profile may be due to increase in both de-novo triglyceride and cholesterol synthesis and intestinal lipid uptake ${ }^{28}$. Moreover, studies have reported that rats with a diet high in fat develop insulin resistance and confirmed hyperglycaemia ${ }^{29}$. The hyper lipid diet increases glucose production by reducing insulin suppression and increasing gluconeogenesis ${ }^{30}$, resulting in elevated plasma glucose levels. In contrast, treatment with AEK in dose of $200 \mathrm{mg} / \mathrm{kg}$ in CD fed rats decreased serum TG, TC, LDL-C, VLDL-C levels which may be due to lowering lipogenesis, enhancing lipolysis, suppressing appetite and reducing lipid absorption ${ }^{31}$. However, AEK did not affect HDL-C level. These results indicate potential lipid lowering activity of AEK. Regarding, treatment with AEK in CD fed rats decreased serum BG level. Some researchers have been reported the beneficial antihyperglycemic effects of Zingiber officinale ${ }^{32}$, Curcuma longa ${ }^{33}$ and Piper nigrum ${ }^{34}$. According to ${ }^{35}$, the normalization of glucose level was possibly by enhancing the secretion of insulin from the $\beta$ - cells of the islets of pancreas or increasing the efficiency of insulin which facilitates the delivery of glucose from blood to target tissues.

The atherogenic index and coronary risk index are strong and reliable indicators of whether or not cholesterol is deposited into tissues or metabolized and excreted ${ }^{45}$.

Furthermore, the atherogenic index is used as a predictor of atherosclerosis and coronary artery disease ${ }^{36,37}$. The increase in cholesterol is associated with the risk of fatty liver and atherosclerosis ${ }^{38}$. The results of study revealed that this level was lower in the AEK-treated group when compared with the CD-fed group. Therefore, AEK was able to ameliorate cardiovascular disease, atherosclerosis, hyperglycemia and dyslipidemia in CD-induced obesity.

Liver function tests are important indicators to reveal the functional status of liver since it is the vital organ involved in detoxification of compounds and in general metabolism. During diet induced obesity, the liver of obese rats displayed characteristic features of hepatic steatosis such as fat accumulation and swelling of rough endoplasmic reticulum and mitochondria in hepatocytes ${ }^{39}$. Raise levels of serum ALT and AST in CD fed rats was observed in the present study which indicated alterations in liver metabolic function. In contrast, treatment with AEK in dose $200 \mathrm{mg} / \mathrm{kg}$ bw has lowered the CD-induced elevated levels of these hepatic enzymes. This finding is justified by the effect of aqueous extract of "Kemite" on liver function in cholesterol-lowering rats obtained by some authors ${ }^{40}$.

\section{CONCLUSION}

The results of the present study demonstrated that that the aqueous extract of Kemite (AEK) has beneficial effects for the inhibition of cafeteria diet induced obesity. The treatment of AEK decreases body weight gain, food intake, blood glucose and lipid levels in serum, liver enzymes in cafeteria diet-induced obese Wistar rats. Aqueous extract of Kemite has excellent potential as an effective antiobesity agent. Further the findings of the study provide scientific evidence for use of Kemite tea in traditional medicine for treating obesity. However, others studies are necessary to confirm its anti-obesity effect and to find its exact mode of action.

\section{REFERENCES}

1. Jung UJ and Choi MS. Obesity and its metabolic complications: the role of adipokines and the relationship between obesity, inflammation, insulin resistance, dyslipidemia and nonalcoholic fatty liver disease. Int J Mol Sci, 2014; 15:6184-223. http://dx.doi.org/10.3390/ijms15046184.

2. Hruby A, Hu FB. The epidemiology of obesity: a big picture. Pharmacoeconomics, $\quad 2015$; 33:673-689. http://dx.doi.org/10.1007/s40273-014-0243-x.

3. Ajlouni K, Khader Y, Batieha A, Jaddou H, El-Khateeb M. An alarmingly high and increasing prevalence of obesity in Jordan. Epidemiol Health (epiH), 2020. http://dx.doi.org/10.4178/epih.e2020040. 
4. World Health Organisation (WHO. Obesity, 2020. https://www.who.int/healthtopics/ obesity\#tab=tab 1. Accessed on 28/5/2020.

5. United Nation Food and Agriculture Organization (UNIFAOObesity on the rise in West Africa, 2019. http://www.fao.org/africa/news/detailnews/en/c/1187047/. Accessed on 04/12/2020.

6. N'Guetta $R, \underline{\text { Yao }} \quad H, \underline{\text { Brou }} \quad \mathrm{I}$, Ekou A, Do $P, \underline{\text { Angoran }}$ I, Kouamé BA_, Konin C, Anzouan-Kacou JB, Kramoh $\mathrm{KE}$, Adoh AM. Prevalence and characteristics of metabolic syndrome among hyper-tensive patients in Abidjan. Ann Cardiol Angeiol, 2016; 65(3): 131-135. http://dx.doi.org/10.1016/j.ancard.2016.04.009.

7. Sable PS, Yan K, Yapi A, Kpebo DD, Ekou KF, Ake-Tano SOP, Tetchi EO, Konan YE, Kouassi D, Wan C. Epidemiologic Profile of Overweight and Obesity in Abidjan, Ivory Coast: A Cross-Sectional Study. Annals of Global Health, 2020; 86(1): 46, 1-10. http://dx.doi.org/10.5334/aogh. 2755.

8. Fazelian S, Namazi N, Heshmati J. Self-treatment with antiobesity medications in overweight and obese. Women in Tehran-Iran. Nutri Food Sci Res, 2014 ; 1 (1) : 114-114. https://www.sid.ir/en/journal/ViewPaper.aspx?id=43594 1.

9. Olson K, Bond D, Wing RR. Behavioral Approaches to the Treatment of Obesity. R । Med J, 2017; 100: 21-4. http://dx.doi.org/10.1111/imj.13474. PMID: 28677316.

10. Narayanaswami V, Dwoskin LP. Obesity: Current and potential_pharmacotherapeutics and targets. Pharmacol Ther, 2017 ; 170:116-47. http://dx.doi.org/10.1016/j.pharmthera.2016.10.015.

11. Kang JG, Park C-Y. Anti-Obesity Drugs: A Review about Their Effects and Safety. Diabetes \& metabolism J, 2012 ; 36:1325. http://dx.doi.org/10.4093/dmj.2012.36.1.13.

12. OECD. OECD guideline for testing of chemicals. Test No. 425: acute oral toxicity: up-and-down procedure, 2008. http://dx.doi.org/10.1787/9789264071049.

13. Darimont $C$, Yurini $M$, Epitaux $M$, Zbinden I, Richelle $M$, Montell E, Martinez AF, Mace K. $\beta 3$-adrenoceptor agonist prevents alterations of muscle diacylglycerol and adipose tissue phospholipids induced by a cafeteria diet. Nutr Metabolism, 2004; $\quad 1$ : 4-12. http://dx.doi.org/10.1186/1743-7075-1-4.

14. Thomas RA, Krishnakumari S. Lipid lowering effects of Myristica fragrans. Int J Pharmacol Pharmaceut Sci, 2016 ; 3 (3) : 10-13.

15. Yakuba MT, Akanji MA, Oladiji AT. Effect of oral administration of aqueous_extract of Fadogia agretis stem bark on some testicular function indices of male rats. Journal of Ethanopharmacol, 2008; 111: 288-292. http://dx.doi.org/10.1016/i.jep.2007.10.004

16. Akase $T$, Shimada $T$, Terabayashi $S$, Ikeya $Y$, Sanada $H$, Aburada M. Antiobesity effects of Kaempferia parviflora in spontaneously obese type II diabetic mice. J Nat Med, $2011 ; 65$ : 73-80. http://dx.doi.org/10.1007/s11418-0100461-2.

17. Friedewald WT, Levy RI, Fredrickson DS. Estimation of the concentration of low density lipoprotein cholesterol in plasma, without use of the preparative ultracentrifuge. Clin $\begin{array}{lccc}\text { Chem, } & 1972 ; & 18, & 499-502 . \\ \text { http://dx.doi.org//10.1093/clinchem/18.6.499. }\end{array}$

18. Nku CO, Ikpi DE, Nna VU, Agiande GU. Altered serum lipid profile in albino Wistar rats following the consumption of Cola nitidarubra (Kola nut). Aust J Basic Appl Sci, 2014 ; 8 : 82-9. http://ajbasweb.com/old/ajbas/2014/August/8289.pdf.

19. Soyinka, OO, Adeniyi, FA, Ajose OA. Biochemical parameters of liver function in artisans occupationally exposed to "vat dyes". Indian J Occup Environ Med, 2007 ; 11 : 76-79. http://dx.doi.org/10.4103/0019-5278.34533.

20. Suastuti NGMAD, Bogoriani N, Putra AA. Activity of Hylocereus Costarioensis's Extract as Antiobesity and Hypolipidemic of Obese Rats. Int J Pharm Res Allied Sci, $2018 ; 7(1): 201-208$.

21. Tauheed AM, Shittu SH, Suleiman MM, Habibu B, Kawu $\mathrm{MU}$, Kobo PI, Yusuf PO. In vivo ameliorative effects of methanol leaf extract of Lawsonia inermis. Linnon experimental Trypanosoma congolense infection in Wistar rats. Int J Vet Sci Med, 2016; 4: 33-40. http://dx.doi.org/10.1016/j.ijvsm.2016.10.005.

22. Sampey $B P, \underline{\text { Vanhoose }} A M, \underline{\text { Winfield }} H M$, Freemerman AJ, Muehlbauer MJ, Fueger PT, Newgard CB, Makowski L. Cafeteria diet is a robust model of human metabolic syndrome with liver and adipose inflammation: comparison to high-fat diet. Obesity (Silver Spring), 2011 ; 19 : 1109-1117. http://dx.doi.org/10.1038/oby.2011.18.

23. Perumal KV, Ja'afar NL, Balan SS, Abidin AZ, Arapoc DJ, Shafie NH, Bahari H. Preventive effect of Elateriospermum tapos seed extract against obese Sprague Dawley rats. Adv Tradit Med, 2020; 20: 107: 113. http://dx.doi.org/10.1007/s13596-019-00394w.

24. Preuss HG, DiFerdinando D, Bagchi M, Bagchi D. Citrus aurantium as a thermogenic, weight-reduction replacement for ephedra: an overview. J Med, 2002 ; 33 : 247-264.

25. Rosenbaum M, Leibel RL, Hirsch J. Obesity. N Engl J Med, 1997 ; 337: 396-7. http://dx.doi.org/10.1056/NEJM199708073370606.

26. Perumal KV, Ja'afar NL, Mat Taib CN, Shafie NH, Bahari H. Antiobesity Activity of Elateriospermum tapos Shell Extract in Obesity-Induced Sprague Dawley Rats. Molecules, 2021 ; 26, 321. https://doi.org/10.3390/ molecules26020321.

27. Martins JM, Carreiras F, Falcao J, Afonso A, da Costa JC. Dyslipidaemia in female overweight and obese patients. Relation to anthropometric and endocrine factors. Int J Obes, $1998 ; \quad 22$ : 164-70. http://dx.doi.org/10.1038/sj.ijo.0800557.

28. Irene PT, Ilias PD, Laskarina MK, George A, loannis SV, Alkisti P, Dimitri PM, Efstratios P, loannis V, Despina NP. Water Soluble Vitamin E Administration in Wistar Rats with Non-alcoholic Fatty Liver Disease. Open Cardiovasc Med J, 2012 ; 6: 88-97. http://dx.doi.org/10.2174/1874192401206010088.

29. Bihan H., Choleau C, Cohen R, Reach G. Obesity, insulin resistance and metabolic complications: what the morbid obesity teaches the doctor. Med Press, 2007 ; 36 : 18931897. http://dx.doi.org/10.1016/i.lpm.2007.04.001. 
30. Martínez-González MÁ, Martinez JA, Hu FB, Gibney MJ, Kearney J. Physical inactivity, sedentary lifestyle and obesity in the European Union. Int J Obes, $1999 ; 23: 1192$ 1201. http://dx.doi.org/10.1038/sj.ijo.0801049.

31. Shivaprasad HN, Gopalakrishna S, Mariyanna B, Thekkoot M, Reddy R, Tippeswamy BS. Effect of Coleus forskohlii extract on cafeteria diet-induced obesity in rats. Pharmacog Res, 2014; 69: 41-45. http://dx.doi.org/10.4103/0974-8490.122916.

32. Nazish I, Ansari SH, Arora P, Ahmad A. Antiobesity activity of Zingiber officinale. Pharmacogn J, 2016; 8 (5) : 440-446. http://dx.doi.org/10.5530/pj.2016.5.5.

33. Mohammed A, Wudil AM, Alhassan AJ, Imam AA, Muhammad IU, Idi A. Hypoglycemic activity of Curcuma longa Linn root Extracts on alloxan induced diabetic rats. Haya: Saudi J Life Sci, 2017; 2 (2) : 43-49. http://dx.doi.org/10.21276/hava.2017.2.2.4.

34. Nazish I, Shaikh F, Sawant G. Does low dose of Piper nigrum extract exert anti-obesity activity? Int J Pharm Pharm Sci, 2020; $\quad 12 \quad$ (5) : 41-46. http://dx.doi.org/10.22159/ijpps.2020v12i5.27942.

35. Kahn BB, Flier JS. Obesity and insulin resistance. J Clin Invest, 106 : 473-481 Hartog MGL, Feskens EJM., Hollman PCH, Katan MB, Kromhouy D, 1993. Dietary antioxidant flavonoids and risk of coronary heart disease: the Zutphen
Elderly Study. Lancet, 2000 ; 342: 1007-1011. http://dx.doi.org/10.1172/JCl10842.

36. Nikniaz Z, Mahdavi R, Nikniaz L, Ebrahimi A, Ostadrahimi A. Effects of Elaeagnus angustifolia L. on lipid profile and atherogenic indices in obese females: A randomized controlled clinical trial. J Diet Suppl, 2016 ; 13: 595-606. http://dx.doi.org/10.3109/19390211.2016.1150933.

37. Cai G, Shi G, Xue S, Lu W. The atherogenic index of plasma is a strong and independent predictor for coronary artery disease in the Chinese Han population. Medicine

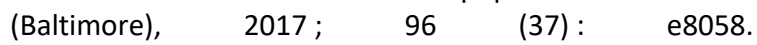
https://doi.org/10.1097/MD.0000000000008058

38. Huang TW, Chang CL, Kao ES, Lin JH. Effect of Hibiscus sabdariffa extract on high fat diet-induced obesity and liver damage in hamsters. Food Nutr Res, 2015 ; 59: 29018. http://dx.doi.org/10.3402/fnr.v59.29018

39. Das N, Sidkar K, Santinath G. Moringa oleifera Lam. leaf extract prevents early liver injury and restores antioxidant status in mice. Indian J Exp Biol, 2012 ; 50: 404-112. http://dx.doi.org/22734251.

40. Mache AG, Njouonkou A-L, Mbofung FMC. Effects of Khaya Tea on Reduction of Obesity and Some Biochemical Parameters of Obeses Rats. J Nutr Obes, $2020 ; 2$ (1): 103. http://dx.doi.org/10.18875.

Source of Support: The author(s) received no financial support for the research, authorship, and/or publication of this article.

Conflict of Interest: The author(s) declared no potential conflicts of interest with respect to the research, authorship, and/or publication of this article.

For any question relates to this article, please reach us at: editor@globalresearchonline.net New manuscripts for publication can be submitted at: submit@globalresearchonline.net and submit_ijpsrr@rediffmail.com 